\title{
ADSORPTION OF METHOMYL BY SOILS OF SOUTHERN SPAIN AND SOIL COMPONENTS
}

\author{
L. Cox, M. C. Hermosin and J. Comejo. \\ Instituto de Recursos Naturales y Agrobiología de Sevilla. \\ C.S.I.C. Apartado 1052. 41080 Sevilla, Spain. \\ (Received in Germany 29 March 1993; accepled 24 May 1993)
}

\begin{abstract}
The adsorption of methomyl (S-methyl $\mathrm{N}$-(methylcarbamoyloxy) thioacetimidate) by 14 soil samples of Southern Spain with different characteristics has been investigated studying the correlation between adsorption and soil properties and the effect of methomyl concentration and soil/solution ratio on adsorption of methomyl by soils. Adsorption has been expressed as the soil-water distribution coefficient $\mathrm{Kd}$. Kd values slightly decreased when soil/solution ratio and methomyl concentration increased. These values indicated that methomyl is adsorbed weakly in soils. Kd values were compared with the soil properties by simple and multiple regression analysis. A highly significant correlation between $\mathrm{Kd}$ and soil organic matter and clay content was observed in every experimental condition. Adsorption of methomyl by clay minerals (two montmorillonites, hectorite, illite and kaolinite) and by humic acid has been investigated as well. The higher adsorption coefficients values obtained with humic acid indicated greater affinity of methomyl molecules for the organic fraction of soils. $\mathrm{Kd}$ data obtained with clay minerals indicate that methomyl is adsorbed not only on the external surfaces of the clay minerals but also in the interlamellar space of the swelling minerals.
\end{abstract}

Key words: methomyl, soil, adsorption, Kd, clay minerals, humic acid.

\section{INTRODUCTION}

Adsorption phenomena of pesticides by soils is one of the most important obstacles for their biological activity in the soil (OSGERBY, 1970). As the extent of adsorption increases, the concentration of the pesticide in the soil water and in the soil air decreases, and consequently the rate of any concentration-dependent process such as biological efficacy decreases (BAILEY and WHITE, 1964; OSGERBY, 1970; MERSIE and FOY, 
1985; WALKER and WELCH, 1989). Soil adsorption of pesticides also affects their transport, mobility and degradability (BAILEY and WHITE, 1970; CALVET, 1989; GRAHAM-BRYCE, 1981; JURY et al., 1987; WALKER and WELCH., 1989), making it an important process in contamination of soils and water.

Numerous studies and reviews have examined soil properties affecting the distribution of pesticides between soluble and adsorbed forms, in order to predict adsorption from the known properties of soils. Soil clay content (WEBER et al., 1986; HERMOSIN et al., 1987; SANCHEZ-CAMAZANO and SANCHEZMARTIN, 1988; HERMOSIN and CORNEJO, 1989) and soil organic matter content (LAMBERT, 1968; KARICKHOFF et al., 1979; REDDY and GAMBRELL, 1987; CHIOU, 1989; SANCHEZ-MARTIN and SANCHEZ-CAMAZANO, 1991 and COX et al. 1992) are specially important in nonionic pesticide adsorption by soils because of their high surface areas and active adsorption sites.

The literature shows that the adsorption of pesticides by soils is not only dependent on physical and chemical properties of the adsorbate and adsorbent, but has been shown in many cases to be affected by experimental variables (HAMAKER and THOMPSON, 1972) such as pesticide concentration and soil/solution ratio. The amount of pesticide adsorbed usually increases with pesticide concentration (GILES et al., 1960). While some authors reported that sorption was independent of soil concentration (Van GENUTCHEN et al., 1977; BOWMAN and SANS, 1985), others reported that adsorption increases when adsorbent concentration decreases (HAMAKER and THOMPSON, 1972; VOICE, 1983; KOSKINEN and CHENG, 1983).

The objetives of this study were to investigate the role of selected physico-chemical properties of some Spanish soils and soil components, such as clay minerals and humic acid, and experimental variables on the distribution of methomyl between dissolved and solid phases using a batch equilibration procedure.

\section{MATERIAL AND METHODS}

The pesticide selected was the insecticide methomyl ( $\mathrm{S}$-methyl $\mathrm{N}$-(methylcarbamoyloxy) thioacetimidate).

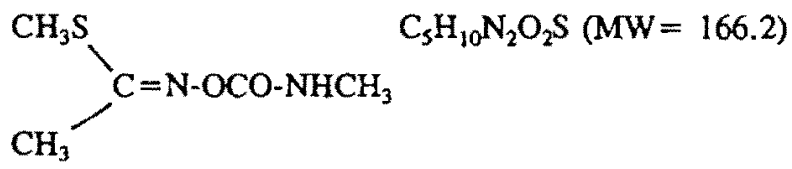

The methomyl used was the high purity compound obtained from Riedel (Pestanal). This insecticide is a crystaline solid of melting point $78-79^{\circ} \mathrm{C}$, v.p. $6.65 \mathrm{mPa}$ at $25^{\circ} \mathrm{C}$ and water solubility at $25^{\circ} \mathrm{C} 58 \mathrm{~g} / \mathrm{Kg}$ (WORTHING and HANCE, 1991). This insecticide is used as foliar spray and also as soil treatment. As soil treatment it is taken up by roots and traslocated.

The 14 soil samples selected for this study are different horizons of 9 types of soils located in Southern Spain, in an intensively cultivated area surrounding the Donana National Park (Figure 1). The soils sampled were air dried and sieved to pass a $2 \mathrm{~mm}$ mesh and stored in a refrigerator. Their physico-chemical properties 
Figure 1. Area of study with indication of sample sites

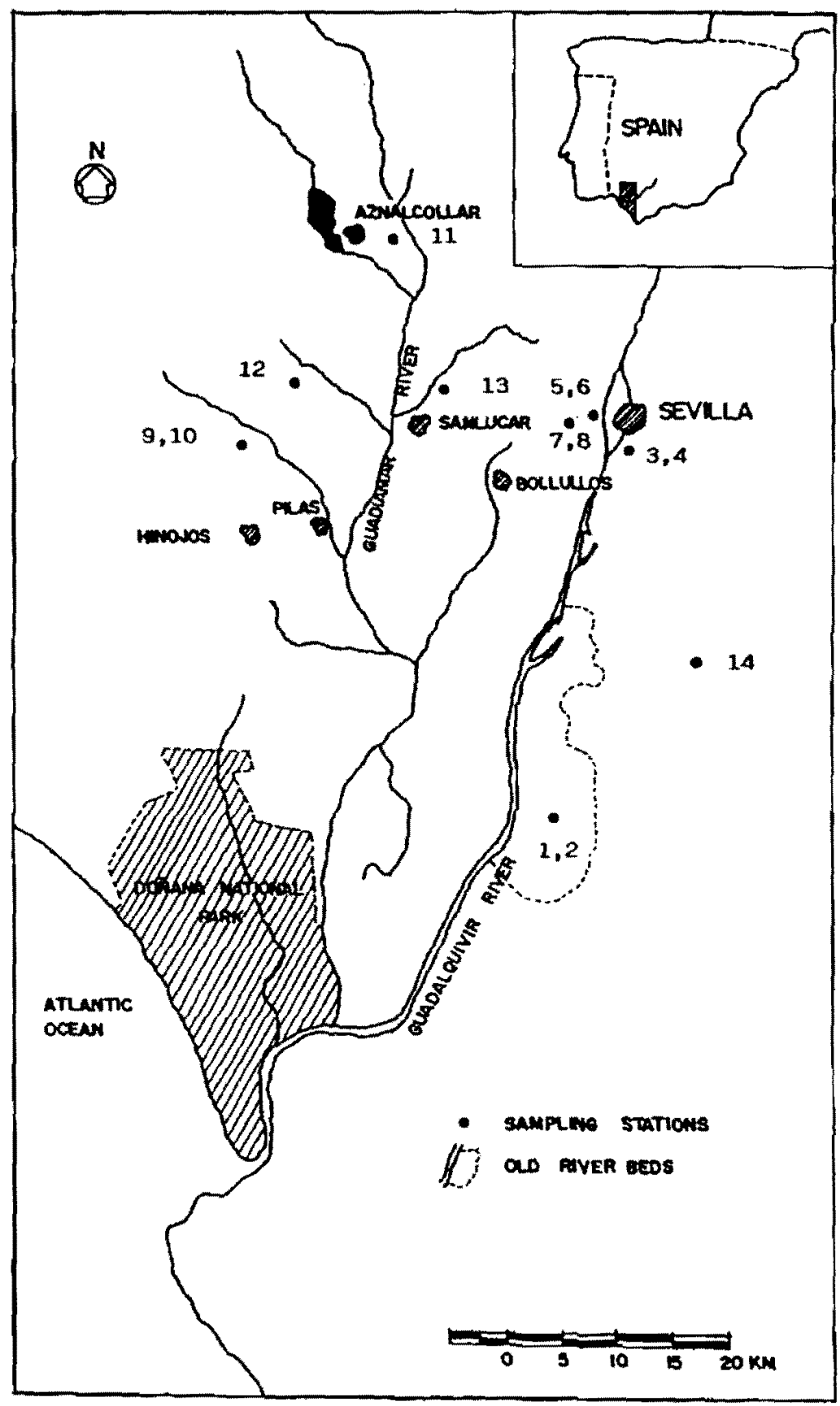

were determined by the usual methodology (HERMOSIN et al, 1987) and the clay mineralogy by X-ray diffraction on oriented specimen (HERMOSIN et al, 1987).

Soils were equilibrated with methomyl initial solution concentration (Ci) $20 \mu \mathrm{M}$ and $50 \mu \mathrm{mM}$. In both cases $0.01 \mathrm{M} \mathrm{Cl}_{2} \mathrm{Ca}$ was used as solvent, in order to promote floculation and to have a constant background 
electrolite concentration. Soil/solution ratios were $1: 5(2 \mathrm{~g} / 10 \mathrm{ml})$ and $1: 2(5 \mathrm{~g} / 10 \mathrm{ml})$. The suspensions were shaken for 24 hours at constant temperature $\left(22 \pm 2^{\circ} \mathrm{C}\right)$ and centrifuged at $12000 \mathrm{rpm}$ at the same temperature. The equilibrium concentration $(\mathrm{Ce}=\mu$ mole/L) of methomyl for each soil sample was measured in the supernatant using a reverse phase high performance liquid chromatography (HPLC) method in a Waters $600 \mathrm{E}$ liquid chomatograph fitted with a $486 \mathrm{UV}$ absorbance detector. The following conditions were used: Nova-Pak column of $150 \mathrm{~mm}$ length $\times 3.9 \mathrm{~mm}$ i.d.; column packing, $\mathrm{Cl}$; flow rate, $1 \mathrm{ml} / \mathrm{min}$; eluent system, 90:10 water-acetonitrile mixture; wavelenght, $232 \mathrm{~nm}$. All determinations were carried out in triplicates. The difference between methomyl initial solution concentration and equilibrium concentration was assumed to be adsorbed.

The amount of pesticide adsorbed has been expressed as the soil-water distribution coefficient Kd:

$$
\mathrm{Kd}=\frac{\mathrm{Cs}(\mu \text { mole adsorbed } / \mathrm{Kg} \text { soil })}{\mathrm{Ce}(\mu \text { mole dissolved } / \mathrm{L} \text { solution })}
$$

Simple and multiple regression analysis between $\mathrm{Kd}$ and soil properties were used to evaluate the factors affecting methomyl adsorption.

Adsorption of methomyl by clay minerals and humic acid has also been studied. The minerals used, supplied by the clay mineral repository of The Clay Mineral Society, were: 1) Three smectites: two montmorillonites-SWy and SAz- and the trioctahedral smectite hectorite (SHCa-1), 2) Illite-O5 and 3) Kaolinite (KGa-2). The humic acid used in the present study has been supplied by Fluka ChemiKa. Samples of SWy montmorillonite were saturated with $\mathrm{K}^{+}, \mathrm{Na}^{+}, \mathrm{Ca}^{2+}, \mathrm{Mg}^{2+}$ and $\mathrm{Fe}^{3+}$ by treating the $<2 \mu \mathrm{m}$ fraction three times with a $1 \mathrm{~N}$ solution of the respective chloride salts, and then washed until Clfree. Humic acid samples were saturated, following tha same procedure, with $\mathrm{Ca}^{2+}$ and $\mathrm{Fe}^{3+}$. Adsorption experiments were done under the same conditions as those used in the soils, except for the amount of adsorbent used, which was $100 \mathrm{mg}$ and $10 \mathrm{mg}$ for clay minerals and humic acid, respectively.

\section{RESULTS AND DISCUSSION}

Soil characteristics. Physico-chemical properties, clay mineralogy and classification are given in Table 1 . It can be seen that the organic matter content (O.M.) of these soils is slightly poor $(0.5-2.5 \%)$ whereas the clay content is generally high (20-67\%). It is worthwhile to consider the illitic character of the soil clays for further discussions.

Adsorption by soils. $\mathrm{Kd}$ values for methomyl at the soil/solution ratios and initial solution concentration $(\mathrm{Ci}=$ $\mu$ mole) studied for each soil are summarized in Table 2. Increasing soil/solution ratio from 1:5 to 1:2 slightly decreased $\mathrm{Kd}$ mean values from 0.75 to $0.64(\mathrm{Ci}=20 \mu \mathrm{M})$ and from 0.53 to $0.47(\mathrm{Ci}=50 \mu \mathrm{M})$ respectively. This is in agreement with other studies (VOICE et al., 1983; KOSKINEN and CHENG, 1983). Changes in 
Table 1. Selected physicochemical properties, clay mineralogy and classification of the soils studied.

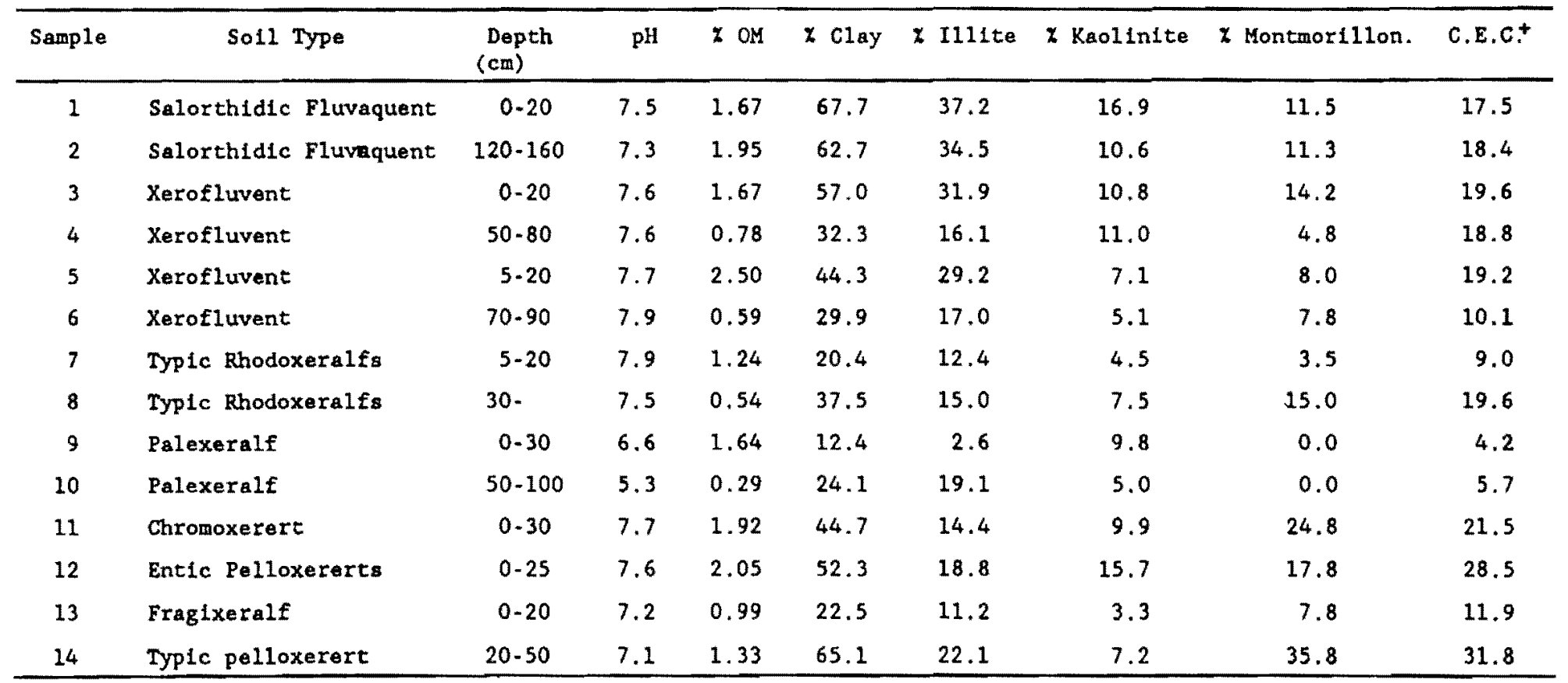

+ mequiv/100 g 
adsorption coefficients due to changes in soil/solution ratios have been attributed to differences in dispersion of soil agregates (GROVER and HANCE, 1970). In suspensions of lower soil/solution ratios there will be greater dispersion and, in consequence, higher adsorption. However, the differences between Kd values for the two concentrations studied and same soil/solution ratio are not important in any case studied, indicating a low affinity of methomyl for studied soils. Table 2 also shows the effect of methomyl initial solution concentration ( $\mathrm{Ci}$ ) on $\mathrm{Kd}$ values. For the 2 soil/solution ratios studied, $\mathrm{Kd}$ values decreased when $\mathrm{Ci}$ increased from $20 \mu \mathrm{M}$ to $50 \mu \mathrm{M}$, because the increment in $\mathrm{Cs}$ values when $\mathrm{Ci}$ increases is smaller than the increment in methomyl equilibrium concentration.

Table 2. Distribution coefficients (Kd= $\mu$ mole $/ \mathrm{Kg} / \mu$ mole $/ \mathrm{L}$ ) for methomyl initial solution concentration $20 \mu \mathrm{M}$ and $50 \mu \mathrm{M}$ varying soil/solution ratio.

\begin{tabular}{|c|c|c|c|c|}
\hline & \multicolumn{2}{|c|}{$\mathrm{Ci}=20 \mu \mathrm{M}$} & \multicolumn{2}{|c|}{$\mathrm{Ci}=50 \mu \mathrm{M}$} \\
\hline \multirow{2}{*}{$\begin{array}{c}\text { Soil } \\
\text { Sample }\end{array}$} & \multicolumn{2}{|c|}{ Soil/solution ratio } & \multicolumn{2}{|c|}{ Soil/solution ratio } \\
\hline & $1: 5$ & $1: 2$ & $1: 5$ & $1: 2$ \\
\hline 1 & 1.69 & 1.62 & 1.30 & 1.00 \\
\hline 2 & 1.22 & 0.95 & 0.90 & 0.74 \\
\hline 3 & 1.46 & 1.46 & 0.98 & 0.92 \\
\hline 4 & 0.31 & 0.33 & 0.15 & 0.11 \\
\hline 5 & 1.42 & 1.24 & 0.79 & 0.76 \\
\hline 6 & 0.18 & 0.20 & 0.22 & 0.19 \\
\hline 7 & 0.56 & 0.44 & 0.39 & 0.45 \\
\hline 8 & 0.35 & 0.22 & 0.26 & 0.19 \\
\hline 9 & 0.33 & 0.27 & 0.32 & 0.20 \\
\hline 10 & 0.08 & 0.05 & 0.07 & 0.06 \\
\hline 11 & 0.80 & 0.62 & 0.49 & 0.39 \\
\hline 12 & 0.90 & 0.83 & 0.62 & 0.59 \\
\hline 13 & 0.78 & 0.47 & 0.39 & 0.36 \\
\hline 14 & 0.50 & 0.54 & 0.42 & 0.40 \\
\hline Means & 0.75 & 0.66 & 0.52 & 0.45 \\
\hline
\end{tabular}


To determine the influence of soil properties on the adsorption of methomyl, simple and multiple linear regression analysis were performed. Simple correlation coefficients ( $r$ ) between $\mathrm{Kd}$ and physicochemical properties of the 14 soil samples are given in Table 3. Best fit multiple regression equations relating Kd for methomyl at each experimental condition to soil properties are given in Table 4. Organic matter (COX et al., 1992), clay and illite contents gave the highest simple and multiple correlation coefficients in every experimental conditions, indicating that the retention of methomyl by soils is determined mainly by these components of the colloidal fraction of soils.

Table 3. Simple correlation coefficients ( $r$ ) between $\mathrm{Kd}$ and some soil properties varying methomyl initial solution concentration $(\mathrm{Ci})$ and soil/solution ratio.

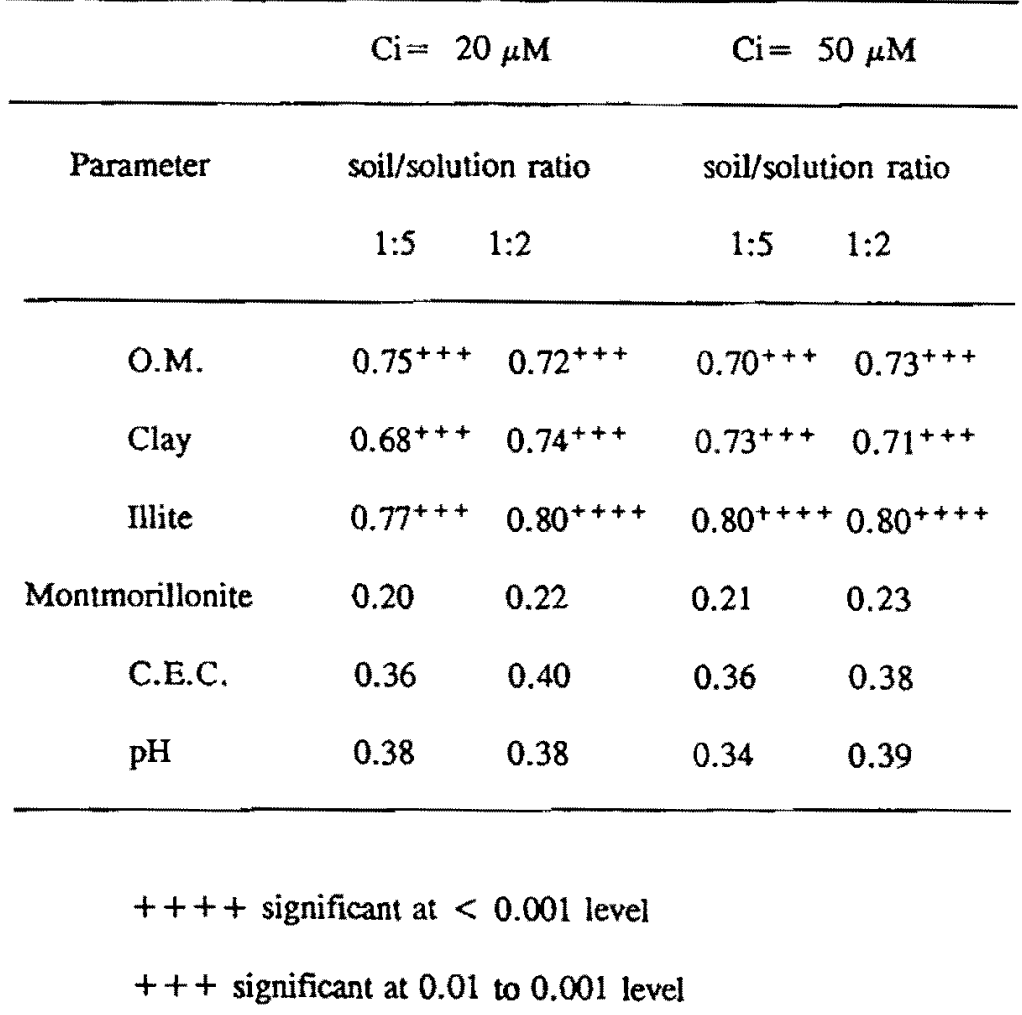

No correlation between $\mathrm{Kd}$ and soil montmorillonite content was observed, in spite of the sorption capacity of this mineral for methomyl, as will be shown below. This could be consequence of the homogeneus composition of the clay fraction of the soils in which the illite fraction is predominant $(r=0.81$ was found between soil clay content and illite content). On the other hand, the high correlation observed between $\mathrm{Kd}$ values and soil illite content could also indicate that this mineral is present in these soils in a very altered form 
(MORENO et al., 1980) giving rise to higher surface areas and cation exchange capacities than the pure compound normally has.

Table 4. Best fit multiple regression equations relating $\mathrm{Kd}$ to soil properties for each experimental condition.

Regression equation

$\mathrm{Ci}=20 \mu \mathrm{M}:$
Correlation coefficient

- Soil/solution ratio $1 / 5$

$$
\begin{aligned}
& \mathrm{Kd}=-0.414+0.418 \text { (\%O.M.) }+0.030 \text { (\% mite) } \mathrm{R}=0.92^{++++} \\
& \mathrm{Kd}=-0.284+0.419(\% \text { O.M. })+0.011 \text { (\% Clay) } \mathrm{R}=0.83^{++++}
\end{aligned}
$$

- Soil/solution ratio $1 / 2$

$$
\begin{array}{ll}
\mathrm{Kd}=-0.454+0.356(\% \text { O.M. })+0.031 \text { (\% Illite) } & \mathrm{R}=0.94^{++++} \\
\mathrm{Kd}=-0.420+0.380(\% \text { O.M. })+0.013 \text { (\% Clay) } & \mathrm{R}=0.85^{++++}
\end{array}
$$

$$
\mathrm{Ci}=50 \mu \mathrm{M} \text {; }
$$

- Soil/solution ratio $1 / 5$

$$
\begin{array}{ll}
\mathrm{Kd}=-0.267+0.246(\% \text { O.M. })+0.022(\% \text { Illite }) & \mathrm{R}=0.92^{++++} \\
\mathrm{Kd}=-0.219+0.240(\% \text { O.M. })+0.010(\% \text { Clay }) & \mathrm{R}=0.83^{++++}
\end{array}
$$

- Soil/solution ratio $1 / 2$

$$
\begin{array}{ll}
\mathrm{Kd}=-0.232+0.236(\% \text { O.M. })+0.018(\% \text { Ilite }) & \mathrm{R}=0.94^{++++} \\
\mathrm{Kd}=-0.182+0.230 \text { (\%O.M. })+0.008 \text { (\% Clay) } & \mathrm{R}=0.83^{++++}
\end{array}
$$


Adsorption by pure soil components. Taking into account the above results and considerations, $\mathrm{Kd}$ values for soil active components such as clay minerals and humic acid were determined. The clay minerals chosen were representative of all mineral components of the clay fraction of these soils (Table 1) and humic acid was chosen as representative of one of most active components of soil organic matter. Table 5 gives these values for three smectites (SWy-Ca ${ }^{2+}, \mathrm{SAz}$ and $\left.\mathrm{SHCa}-1\right)$, illite, kaolinite and humic acid and $50 \mu \mathrm{M}$ methomyl initial solution concentration. This Table also summarizes the surface properties of the clay minerals studied.

Table 5. Distribution coefficients $\mathrm{Kd}(\mu \mathrm{mole} / \mathrm{Kg} / \mu$ mole/ $\mathrm{L}$ for adsorption of methomyl $(\mathrm{Ci}=50 \mu \mathrm{M})$ by $9 \mathrm{Swy}-$ $\mathrm{Ca}^{2+}$ and SAz montmorillonites, SHCa-1 hectorite, illite, kaolinite and humic acid samples and cation exchange capacity (C.E.C.), layer charge and external $\left(\mathrm{N}_{2}\right)$ and total (glycerol) surface area of the minerals.

\begin{tabular}{|c|c|c|c|c|c|}
\hline Sample & $\mathrm{Kd}$ & $\begin{array}{c}\text { C.E.C." } \\
(\mathrm{meq} / 100 \mathrm{~g})\end{array}$ & $\begin{array}{l}\text { Layer charge } \\
\text { (mol/unit cell) }\end{array}$ & $\begin{array}{l}\text { Surface } \\
\mathrm{N}_{2}\end{array}$ & $\begin{array}{l}\text { area }\left(\mathrm{m}^{2} / \mathrm{g}\right)^{n} \\
\text { Glycerol }\end{array}$ \\
\hline $\mathrm{SWy}-\mathrm{Ca}^{2+}$ & 9.58 & 76.4 & 0.68 & 31.8 & 662 \\
\hline$S A z$ & 4.5 & 120.0 & 1.13 & 97.4 & 820 \\
\hline SHCa-1 & 9.43 & 43.9 & 0.31 & 63.2 & 486 \\
\hline Illite & 1.56 & 26.6 & 1.45 & 101.0 & -100 \\
\hline Kaolinite & 0.5 & 3.3 & 0.00 & 23.5 & 25 \\
\hline Humic acid & 399.45 & -- & - & - & $-\cdots$ \\
\hline
\end{tabular}

\footnotetext{
a Van Olphen and Fripist, 1979.

b Toul charge calculated from tolal chemical anulysis

(Isyres and Boyd, 1991).
}

Kd values obtained for humic acid samples were much higher than those obtained for the clay mineral samples, indicating that organic matter has much greater affinity for methomyl than clay minerals, eventhough the high water solubility of the pesticide. Table 5 also shows greater adsorption of methomyl on smectites than on the other two minerals, because of the higher C.E.C. and surface area, that make this mineral very active in soil adsorption processes (BAILEY and WHITE, 1970). This suggested that methomyl molecules could adsorb not only on the external surface of the clay minerals but also on the interlamellar space of the smectite, because of the swelling properties of these minerals which have internal surfaces accesible to organic polar 
molecules (MORTLAND, 1970). The Kd values obtained for the different smectites with different layer charge seem to confirm that methomyl adsorption occurred at the interlamellar spaces of these minerals. Kd values increased when the layer charge of the smectite decreased (Table 5). This is because the opening of the silicate layer is much easier. Similar results were reported by Hermosín et al., 1991 for maleic hidrazide adsorption on different montmorillonites.

$\mathrm{Kd}$ values for homoionic montmorillonites at $50 \mu \mathrm{M}$ methomyl initial solution concentration are reported in Table 6. Ionic potentials of the exchangeable cations in the samples and the pH found in the suspensions of methomyl solution-clay are given in this Table. Kd values for homoionic montmorillonites decreased as the ionic potential of the exchangeable cation increased, except for the $S W y-\mathrm{Fe}^{3+}$ sample. The increase in $\mathrm{Kd}$ values when the ionic potential of the exchangeable cation decreases indicates also interlamellar adsorption (HERMOSIN et al., 1991; SANCHEZ-MARTIN and SANCHEZ-CAMAZANO, 1991) of methomyl. The adsorption of polar molecules at the interlamellar spaces of the montmorillonite is facilitated by the low ionic potential of the exchangeable cation. This parameter determines the attraction layer-cation-layer and the energy of the polar molecule-cation bond. As the ionic potential decreases, the opening of the silicate layer is easier and the substitution of the hidration water molecules associated to the exchangeable cations by methomyl is facilitated (HERMOSIN et al., 1991; SANCHEZ-MARTIN AND SANCHEZ-CAMAZANO, 1991). The exception in this behaviour is the $S W y-\mathrm{Fe}^{3+}$ sample. The higher $\mathrm{Kd}$ values obtained could be due to the low $\mathrm{pH}$ found in the suspension, which suggests that the montmorillonite sample is not homoionic $\left(\mathrm{H}^{+} / \mathrm{Fe}^{3+}\right.$ montmorillonite). At this $\mathrm{pH}$, methomyl molecules could be more positively charged, with cationic character, which can also explain this greater adsorption. The higher adsorption found for the potassium sample could also explain the high adsorption capacity of the soils rich in altered illite, which is a potassium saturated mineral.

An apparent contradiction seems to occur between the methomyl adsorption results obtained for soil clays and the corresponding for "pure" clay minerals. Table 3 shows a good correlation coefficient ( $r$ ) between $\mathrm{Kd}$ and soil illite content and a poor $\mathrm{r}$ between $\mathrm{Kd}$ and soil montmorillonite content. Meanwhile, Kd values for every smectite studied are higher than for illite (Table 5). However it is neccesary to take into account the high illite content and low smectite content in these soils. Moreover, these illitic soils seem to be weathered (ARAMBARRI and TALIBUDEEN, 1987) and have an important swelling character like smectites, and hence a higher surface area and C.E.C..

Table 6 shows the distribution coefficients for the adsorption of $50 \mu \mathrm{M}$ methomyl solution by humic acid (HA) and $\mathrm{HA}$ saturated with $\mathrm{Ca}^{2+}$ and $\mathrm{Fe}^{3+}$ samples. $\mathrm{Kd}$ values for cation saturated humic samples were much lower than those obtained for the HA sample. In the humic acid, the inorganic exchangeable cation substitutes the hidrogen atom of the acidic ( $\mathrm{COOH}$ or fenolic $\mathrm{OH})$ groups forming salts which lower the effective hydrophobic surface area (WERSHAW, 1986). On the other hand, the blocked $\mathrm{COOH}$ or $\mathrm{OH}$ groups of the HA make them enable to bind methomyl molecules by H-bonds as usual in this type of adsorption 
(WEED and WEBER, 1975; SENESI and TESTINI, 1980; MAQUEDA et al., 1983). These results seem to indicate that retention of methomyl by humic acid occurred by hydrophobic and $\mathrm{H}$-bond forces.

Table 6. Distribution coefficients $\mathrm{Kd}(\mu$ mole $/ \mathrm{Kg} / \mu$ mole $/ \mathrm{L})$ for adsorption of methomyl $(\mathrm{Ci}=50 \mu \mathrm{M})$ by humic acid (HA) and homoionic samples of HA and SWy montmorillonite, ionic potential of the saturating cation and $\mathrm{pH}$ of the methomyl-montmorillonite suspensions.

\begin{tabular}{|c|c|c|c|c|c|}
\hline Sample & Kd & Sample & $\mathrm{Kd}$ & $\begin{array}{l}\text { Cation Ionic } \\
\text { Potential } \\
\left(\mathrm{nm}^{-1}\right)\end{array}$ & $\begin{array}{l}\mathrm{pH} \text { of } \\
\text { suspension }\end{array}$ \\
\hline HA & 399.45 & $\mathrm{SWy}-\mathrm{Mg}^{2+}$ & 6.27 & 27.8 & 6.7 \\
\hline $\mathrm{HA}-\mathrm{Ca}^{2+}$ & 181.78 & $\mathrm{SWy}-\mathrm{Ca}^{2+}$ & 9.58 & 20.2 & 6.9 \\
\hline \multirow[t]{3}{*}{$\mathrm{HA}-\mathrm{Fe}^{3+}$} & 142.21 & SWy-Na ${ }^{+}$ & 17.49 & 9.8 & 4.4 \\
\hline & & SWy-K ${ }^{+}$ & 46.67 & 7.3 & 5.5 \\
\hline & & $\mathrm{SWy}-\mathrm{Fe}^{3+}$ & 57.77 & 40.6 & 2.5 \\
\hline
\end{tabular}

Spowito, 1984 .

\section{CONCLUSIONS}

The results of this study showed that the retention of methomyl by the soils studied is determined mainly by soil organic matter and clay content, specially illite because of its high content and alteration degree. Distribution coefficients $\mathrm{Kd}$ slightly decreased when soil/solution ratio increased from $1 / 5$ to $1 / 2$ and when methomyl initial solution concentration increased from $20 \mu \mathrm{M}$ to $50 \mu \mathrm{M}$. The adsorption of methomyl by pure soil components indicated greater affinity of methomyl for humic acid than for clay minerals. Kd values for the adsorption of methomyl were much greater for the untreated humic acid samples than for the cation saturated samples. The study of the adsorption of methomyl by clay minerals indicated greater adsorption of the pesticide on smectites, which increased as layer charge and ionic potential of the saturating cation decreased, indicating that adsorption may occur in the interlamellar space of these minerals.

\section{ACKNOWLEDGEMENTS}

This project has been supported partially by Junta de Andalucia through Research Group No, 4092 and CICYT through Project No. PB-87-240

\section{REFERENCES}

Arambarri, P. and Talibudeen, O. 1987. Changes in the mineralogy of a cultivated marsh soil caused by simulated weathering. Journal of Soil Science 38: 13-17. 
Bailey, G.W. and White, J.L. 1964. Review of adsorption and desorption of organic pesticides by soil colloids, with implications conceming pesticide bioactivity. J. Agric. Food Chem. 12: 324-332.

Bailey, G.W. and White, J.L. 1970. Factors influencing the adsorption, desorption and movement of pesticides in soils. Residue Review 32: 29-92.

Bowman, B.T. and Sans W.W. 1985. Partitioning behaviour of insecticides in soil-water systems: I. Adsorbent concentration effects. J. of Environ. Qual. 14: 265-269.

Calvet, R. 1989. Adsorption of organic chemicals in soils. Environ. Health Perspectives 83: 145-177.

Chiou, C.T. 1989. Theoretical considerations of the partition uptake of non-ionic organic compounds by soil organic matter. In Reactions and movement of organic chemicals in soils. SSSA Special Publication No. 22, pp. 1-29.

Cox, L.; Hermosin, M.C. and Comejo, J. 1992. Distribution coefficient of methomyl in soils from different depths. Fresenius Environ. Bull. 1: 445-449.

Giles, C.H.; MacEwan, T.J.; Nakhwa, S.N. and Smith, D. 1960. Studies in adsorption. Part XI. A system of classification of solution adsorption isotherms and it's use in diagnosis of adsorption mechanism and in measurement of specific surface area of solids. J. Chem. Soc.: 3973-3993.

Graham-Bryce, I.J. 1981. The behaviour of pesticides in soil. In The chemistry of soil processes. D.J. Greenland and M.H.B. Hayes (eds.). John Wiley \& Sons, Chichester, pp. 621-670.

Grover, R. and Hance, R.J. 1970. Effect of ratio of soil to water on adsorption of linuron and atrazine. Soil Science 109: 136-138.

Hamaker, J.W. and Thompson, J.M. 1972. Adsorption. In Organic chemicals in the soil environment (I). C.A.I. Goring and J.W. Hamaker (eds.). Marcel Dekker, New York, pp. 49-143.

Hermosin, M.C.: Cornejo, J. and Perez-rodriguez, J.L. 1987. Adsorption and desorption of maleic hidrazide as a function of soil properties. Soil Sci. 144: $250-256$.

Hermosin, M.C. and Cornejo, J. 1989. Assesing factors related to pesticide adsorption by soils. Toxicol. and Environ. Chem. 25: 45-55.

Hermosín, M.C.; Roldán, I. and Cornejo, J., 1991. Adsorption-desorption of maleic hidrazide on mineral soil components. J. Environ. Sci. and Health B26(2): 165-183.

Jaynes, W.F. and Boyd, S.A., 1991. Clay mineral type and organic compound sorption by hexadecyltrimethylammonium-exchanged clays. Soil Sci. Soc. Am. J. 55: 43-48.

Jury, W.A.; Focht, D.D. and Farmer, W.J. 1987. Evaluation of pesticide groundwater pollution potential from standard indices of soil chemical adsorption and biodegradation. J. Environ. Qual. 16: 422-428.

Karickoff, S.W.; Brown, D.S. and Scott, T.A. 1979. Sorption of hidrophobic pollutants on natural sediments. Water Research 13: 241-248.

Koskinen, W.C. and Cheng, H.H. 1983. Effects of experimental variables on 2,4,5-T adsorption-desorption in soil. J. Environ. Qual. 12: 325-330.

Lambert, S.M. 1968. Omega: A useful index for soil sorption equilibria. J. Agric. Food Chem. 16: 340-343. Maqueda, C; Perez-Rodriguez, J.L.; Martin, F. and Hermosín, M.C., 1983. A study of the interactions 
between chlodimeform and humic acid from a Typic Chromoxerert soil. Soil Sci. 136: 75-81. Mersie, W. and Foy, C.L. 1985. Phytotoxicity and adsorption of chlorsulfuron as affected by soil properties.

Weed Sci. 33: 564-568.

Moreno, F.; Arrue, J.L.; Murillo, J.M.; Perez, J.L. and Martin, J., 1980. Mineralogical composition of clay fraction in marsh soils of SW Spain. Polish Joumal of Soil Science 13: 67-72.

Mortland, M.M., 1970. Clay organic complexes and interactions. Adv. Agron. 22: 75-117.

Osgerby, J.M. 1970. Sorption of un-ionised pesticides by soils. In Sorption and transport processes in soils. SCI Monograph No. 37, pp. 63-78.

Reddy, K.S. and Gambrell, R.P. 1987, Factors affecting the adsorption of 2,4-D and methyl-parathion in soils and sediments. Agric., Ecosys. and Environ. 18: 231-241.

Sanchez-Camazano, M. and Sanchez-Martin, M.J. 1988. Influence of soil characteristics on the adsorption of pirimicarb. Environ., Toxicol. and Chem. 7: 559-564.

Sanchez-Martin, M.J. and Sanchez-Camazano, M., 1991. Adsorption of chloridazon by soils and their components. Weed Science 39: 417-422.

Senesi, N. and Testini, C., 1980. Adsorption of some nitrogenated herbicides by soil humic acids. Soil Sci. 130: 314-320.

Sposito, G., 1984. The reactive solid surfaces, In The Surface Chemistry of Soils. Oxford University Press, New York, pp. 1-46.

Van Genutchen, M.T.; Wierenga, P.J.0 and O'Connor. 1977. Mass transfer studies in sorbing porous media: III Experimental evaluation with 2,4,5-T. Soil Sci. Soc. Am. J. 41: 278-285.

Van Olphen, H. and Fripiat, J., 1979. Data Handbook for clay materials and other non-metallic minerals. Pergamon Press, Oxford.

Voice, T.C.; Rice, C.P. and Weber, T.J. 1983. Effect of solid concentration on the sorptive partitioning of hidrophobic pollutants in aquatic systems. Environ. Sci. Technol. 17: 513-518.

Walker, A. and Welch, S.J. 1989. The relative movement and persistence in soil of chlorsulfuron, metsulfuronmethyl and triasulfuron. Weed Research 29: 375-383.

Weber, J.B.; Shea, D.H, and Weed, S.B., 1986. Fluoridone retention and release in soils. Soil Sci. Soc. Am. J. $50: 582-588$.

Weed S.B. and Weber, J.B., 1975. Pesticide-organic matter interactions. In Pesticides in Soils and Waters. W.D. Guenzi (Ed.) SSSA, Madison, WI. pp 39-66.

Wershaw, R.L. 1986. A new model for humic materials and their interactions with hydrophobic organic chemicals in soil-water or sediment-water systems. J. Contam. Hydrol. 1: 29-45.

Worthing, C.R. and Hance, R.J., 1991. The Pesticide Manual. BCPC, Surrey, U.K.. 